\title{
Motyvacija viešajame sektoriuje - motyvacinių alternatyvų teorinès įžvalgos Maslowo poreikių hierarchijos kontekste
}

\author{
Ramūnas Vanagas, Adomas Vincas Rakšnys \\ Mykolo Romerio universitetas \\ Ateities g. 20, LT-08303 Vilnius \\ doi:10.13165/VPA-14-13-2-10
}

Anotacija. Straipsnyje nagrinejama Maslowo teorija viešojo administravimo modeliu metamorfozès kontekste. Apžvelgiant teorijos anatomija bei pritaikant jos logika analizuojant tradicini viešojo administravimo modeli, atskleidžiama kylanti problema, susijusi su aukščiausiu saviraiškos veiksniu valstybès tarnybos kontekste. Taip pat nagrinejamos galimos individualistinès saviraiškos veiksnio neigiamos implikacijos ypatingai naujosios viešosios vadybos koncepcijoje. Siekiant reintegruoti Maslowo teorija, naujajame viešajame valdyme kaip alternatyva pasiūloma atlikti teorini grupavima, ’̣diegiant Franklio savitranscendenciją kaip šio modelio motyvacini normatyva.

Raktažodžiai: motyvacija, viešasis sektorius, naujasis viešasis valdymas, savitranscendencija, žmogaus poreikiai.

Keywords: motivation, public sector, new governance, self-transcendence, human needs.

\section{İvadas}

Vykstant viešojo administravimo reformoms, siekiant optimizuoti ir modernizuoti viešaji sektorių, vis daugiau dèmesio skiriama personalo valdymo tobulinimo tendencijoms, žmogiškujų išteklių svarbai, motyvavimui ir motyvacijai. Šie aspektai neabejotinai reikšmingi dẻl to, jog valstybės tarnautojų motyvacija viešojo administravimo modeliu transformacijos kontekste gali tapti svarbiu parametru, determinuojančiu atliekamos veiklos vertybines nuostatas, valstybès tarnautojų 
prisitaikymą prie reformų, orientaciją ị viešajji interesą sprendimų ígyvendinimo atžvilgiu bei individualias moralines laikysenas korupcinès elgsenos kontekste. Straipsnyje netradiciškai siekiama pademonstruoti, jog filosofinis diskursas valstybės tarnautojų motyvavimo prasme yra dar neišnaudotas instrumentarijus. Vis dèlto, kaip pastebi C. Stivers, ,biurokratai ir kiti viešojo sektoriaus tarnautojai kartais didžiuojasi galẻdami atsiriboti nuo filosofijos kaip nuo nepraktiškos ir apsimestinès. Tačiau dauguma žmonių viešajame gyvenime iš visų jẻgų stengiasi atrasti prasmę, kuri suteiktų žmogišką pojūtį, jog jie nešvaisto savo gyvenimo“ [39, p. 19]. Todèl autoriai išsikèlè tikslą išnagrinèti klasikinès A. H. Maslowo poreikių hierarchijos teorijos ir jos logikos pritaikomumo klausimus viešojo administravimo modelių transformacijos kontekste atliekant teorinį grupavimą, susijusị su Maslowo aukščiausiu saviraiškos veiksniu, pakeičiant ji filosofiniu V. Franklio savitranscendencijos (savitranscendencija - orientacija ị kitus peržengiant asmenines ribas - aut.) faktoriumi, atskleidžiant jo kaip motyvacinio normatyvo naujojo viešojo valdymo modelyje svarbą. Autorių požiūrị sustiprina ir tai, jog tiriant motyvaciją išryškèja metodologinio pobūdžio problema - akademiniame diskurse nèra vienos nuomonès, kuri mokslo sritis turètų ją tirti ar kokie individų parametrai turètų būti tiriami, todèl straipsnyje siekiama įvertinti ir alternatyvius filosofinius metodus. Straipsnio objektu pasirinktas Maslowo poreikių hierarchijos teorijos pritaikomumas ir reintegracija viešojo administravimo modelių metamorfozės kontekste. Problema išryškinama kaip amerikietiškajai kultūrai būdingo individualizmo ir iš jo kylančių neigiamų aspektų sutaikymas valstybès tarnybos motyvacinèje perspektyvoje. Parenkant kitokio pobūdžio teorinį apvalkalą aukščiausiam Maslowo teorijos veiksniui teoriją būtų galima naudingai reintegruoti dabartiniame besiformuojančiame dvasingesniame naujajame viešajame valdyme, tokiu būdu siekiant išvengti teorinių įtampų tarp valstybẻs tarnautojų moralinių normų, viešojo administravimo tikslų, pilietinès visuomenès ir ekonomizuotų efektyvumo rodiklių, amerikietiškosios individualizmo kultūros, kuri sietina su savanaudiškumo, indiferentiškumo ir korupcijos aspektais. Autorių nuomone, tema aktuali pirmiausiai politikams, suinteresuotiems efektyviu viešosios politikos igyvendinimu ir valstybės tarnybos skaidrumu. Itraukiant Maslowo teoriją, papildytą Franklio savitranscendencijos faktoriumi, i dabartines valstybès tarnybos motyvavimo metodikas nesiekiama vien tik deklaruoti etinị imperatyvą, bet greičiau suteikti papildomą priemonę, nereikalaujančią valstybès lěšų, integruojant ją ị bendrosios žmogiškosios motyvacijos kontekstą. Aktualumas akivaizdus ir viešojo sektoriaus žmogiškųjų išteklių vadovams, siekiantiems užtikrinti motyvuotą valstybės tarnybą, viešųjų paslaugų teikimo kokybę. Pasiūlant lengvai suprantamą itin išpopuliarējusią motyvacijos sistemą, daugeli kitu turinio motyvacijos teorijų, kaip F. Herzbergo [17], D. McGregoro [29], D. McClelando [28], C. Alderferio [1], ị modifikacijų pagrindu tapusią Maslowo poreikių hierarchijos motyvacijos teoriją integravus Franklio komponentą, sukuriama galimybe sintezuoti individualius asmens tikslus su valstybės tarnautojo misija per 
motyvacijos kontekstą, vertybiškai ịprasminant atliekamą veiklą ir taip sukuriant galimybę užtikrinti darnų valstybinio aparato funkcionavimą.

Darbo metodai: straipsnyje taikomi literatūros analizès ir lyginamosios analizès metodai, lyginami viešojo administravimo modeliai.

\section{Poreikių hierarchijos teorijos charakteristikos}

Vieną iš svarbiausių turinio motyvacijos poreikių teorijų paskelbė amerikiečiu psichologas Abrahamas Haroldas Maslowas [26]. Maslowas kaip humanistinės psichologijos atstovas savo darbuose orientavosi ị neriboto žmogiškojo kūrybinio potencialo atskleidimą, asmeninių aspiracijų, sveiko ir sėkmès lydimo žmogaus poreikių refleksiją, vidinès motyvacijos svarbą [7]. Pasak Kumaro [20], akcentuotini Maslowo teorijos integralumo, paprastumo ir populiarumo aspektai. Kiti autoriai, kaip Gruyteris [15], linkę išskirti poreikių hierarchijos teorijos pripažinimą tiek akademiniame, tiek verslo diskurse, tačiau akademikai, pvz., Wahba ir Bridwellas [43], linkę atsargiau vertinti Maslowo ịžvalgas bei pačios teorijos validumą, atsižvelgiant ị, jų nuomone, empirinių ịrodymų trūkumą, kai kurias Maslowo idejjas traktuojant kaip labiau teorinès sąmonès projekciją.

Nepaisant kritikos, jog Maslowo teorija orientuota i grynai amerikietiškąją kultūrą, Maslowo teorija ir jos logika žmogaus poreikių hierarchijos atžvilgiu ir toliau pritaikoma ịvairaus spektro studijose, skirtingame geografiniame ir sociokultūriniame lauke: Tikkanena [42] Suomijoje, Olu Ogunrinas ir Akerele [30] Nigerijoje, Gobinas, Teeroovengadumas, Bye Becceea ir Teeroovengaduma [14] Mauricijuje, Keogh [18], Stumas [41] Jungtinèse Amerikos Valstijose, Al Meeras [2] Saudo Arabijoje, Akroush, Abu-ElSamenas, Samawi, Odetallah [24] Jordanijoje, Barnesas ir Pressey [3] Anglijoje, Cao, Jiang, Bin Oh, Li, Liao, Chenas [6] Kinijoje. Remiantis tarpkultūriniu pritaikomu, galima teigti, jog Maslowo teorijos svarba ir itaka yra akivaizdi tiek verslo, tiek privataus sektoriaus struktūrose, jos kontroversiškumo ir ambivalencijos sukeltos akademinès batalijos tarp teorijos antagonistų ir apologetų tebevyksta iki šiol, o žmogaus poreikių schematizavimas kaip penkių poreikių piramide motyvacijos kontekste igauna klasikos statusą. Nagrinejjant Maslowo motyvacijos sistemą darosi akivaizdu, jog teorija pasižymi griežta struktūra bei asmens vidinių poreikių diferenciacija ị penkis lygmenis: gali būti skiriami fiziologiniai poreikiai, saugumo poreikiai, meilès ir bendravimo poreikiai, savivertès poreikiai, saviraiškos poreikiai [26]. Šie faktoriai yra apibrěžiami ir susisteminami hierarchine tvarka. Patenkinus pirminès grupès poreikius pereinama ị kitą etapą. Motyvacijos požiūriu svarbu paminèti, jog teorija remiasi prielaida, jog nepatenkintas poreikis sukelia frustraciją, tampa skatinančiu, motyvaciniu veiksniu. Taip pat akivaizdu, jog Maslowas [26] pabrěžia motyvacinių priežasčiu nuoseklią evoliuciją, kitaip tariant, vyksta veiksnių sudètingejjimas ir augimas viena kryptimi, nuo žemiausiųjų iki aukščiausiųjų motyvacinių indikatorių. Asmuo, patenkinęs fiziologinius poreikius, pradès rūpintis saugumo poreikiais, patenkinęs saugumo, 
susitelks ties socialiniais poreikiais ir tokiu būdu kils saviraiškos poreikių link [8]. Kita vertus, būtina paminèti, jog galima ir žmogaus poreikių degradacija, o ne vien kilimas aukštyn hierarchiniais laiptais [40]. Trumpai apžvelgus bendrąsias teorijos charakteristikas, derètų iškristalizuoti esminius niuansus, susijusius su aukščiausiuoju poreikių hierarchijos teorijos saviraiškos veiksniu.

Pirmasis svarbus faktorius yra tai, jog Maslowas [26] pabrèžia hierarchijos svarbą - nepatenkinus pirminių poreikių, negalima kilti toliau. Vis dèlto dauguma autorių linkę kvestionuoti šią teorinę ižvalgą, pateikdami savąją jos interpretacinę versiją, atkreipdami dėmesị ị badaujančio menininko fenomeną. Pasak S. Kermally, „kai kuriais atvejais žmonès, pavyzdžiui, Rembrandtas ar Van Gogas, siekė savo saviraiškos poreikio, nors ir nesugebejjo visiškai patenkinti fiziologinių poreikių“ [19, p. 31]. Vadinasi, remiantis autoriumi, nagrinejjant istorinę mintį, daroma prielaida, jog esama atvejų, kurie paneigia griežtos hierarchijos idèją, kai menui atsidavę žmonès, ne iki galo patenkinę žemesnių grandžių poreikius, atsiduoda aukštesniesiems, pereidami prie saviraiškos. Tai patvirtina ir austrų psichoterapeutas bei buvęs Aušvico kalinys Viktoras Franklis [12] teigdamas, kad menas gali egzistuoti ir koncentracijos stovykloje. Paradoksalu, tačiau tai būtent ir išryškina, jog net ir dehumanizuotomis sąlygomis žmogus gali atsiduoti aukštesniesiems poreikiams bei siekiams. Tačiau derètų pabrěžti, jog, kaip pastebi Maslowas [27], egzistuoja esminis skirtumas tarp pakankamo ir galutinio, arba absoliutaus, poreikių patenkinimo siekiant jų evoliucijos. Akivaizdu, jog būtinybė patenkinti poreikị siekiant judejimo kito poreikio link neimplikuoja ji patenkinti absoliučiai, tai svarbu suvokti, siekiant išvengti neaiškumo ir retorinio triukšmo, susijusio su poreikių gradacijos nesilaikymo aspektu.

Antrasis svarbus aspektas nagrinejjant saviraišką yra tai, jog Maslowo teorijos kontekste kyla sunkumų, siekiant paaiškinti motyvaciją savižudybei, kylančią ypatingais atvejais tarp individų, kurie poreikių hierarchijos teorijos atžvilgiu jau patenkinę visus pirminius poreikius ir yra atsidūrę saviraiškos faktoriaus lygmenyje [23]. Tai tampa ypatingai aktualu nagrinejjant tarptautini pripažinimą pelniusių garsenybių biografijas. Straipsnio autoriai daro prielaidą, jog tai susiję su pačios Maslowo teorijos konstrukcija ir psichologo asmeninèmis natūralistinès filosofijos pozicijomis. Humanistiné logika be transcendentinių nuostatų aukščiausiame poreikių hierarchijos lygmenyje neišvengiamai patirs fiasko, nes saviraiškos kontekste žmogus praras tolesnes tobulejjimo gaires, o tai gali sukelti vertybinę krizę, kurios nepavyks kompensuoti materialistinemis išraiškomis ir, kaip patvirtina istoriniai atvejai, tai dažnai implikuoja savidestrukcinio mechanizmo aktyvavimą.

Trečiasis svarbus komponentas yra tai, kad pačių poreikių lygis gali skirtis priklausomai nuo žmonių kultūros ir geografinio lauko [36]. Nevienodas žmonių suvokimas, patirtys ir aspiracijų lygmuo suponuoja tai, jog kai kuriems individams svarbiausias faktorius gali būti ne saviraiška, o saugumas, pastovumas ir garantijos darbe. Dar kitiems svarbiausi bus kolektyviniai bendravimo bei socialumo poreikiai. Nors straipsnio autoriai ir parode plataus spektro teorijos pritaikomumą, 
multikultūrinèje erdvėje nemažiau svarbu paminèti dar vieną akcentą, susijusị su postmodernios epochos būkle. Ši kritika yra neatsiejama nuo postmodernistinio diskurso ir nepasitikejjimo Maslowo teorijos metanaratyviniu (metanaratyvas - universalaus pritaikomumo siekianti teorija, sujungianti pavienes žinias - aut.) statusu, kaip bendrame mokslo metodologijos kontekste tai matė J. F. Loytardas, akcentuodamas, jog postmodernioje epochoje vyrauja daugybé mažų naratyvų, postmodernioje visuomenèje yra žiūrima su nepasitikèjimu ị bet kokią universalaus statuso siekiančią teoriją [22]. Kita vertus, būtina išaiškinti, jog siekiant universalaus bendros žmogaus motyvacijos teorijos statuso Maslowo ịžvalgų ir sisteminio požiūrio nepakanka, tačiau nemažiau svarbu atkreipti dėmesị ị tai, jog egzistuoja skirtumas tarp metanaratyvinès žmogiškosios motyvacijos teorijos ir metanaratyvinės individo darbo motyvacijos teorijos. Kaip pastebi M. Blaskova ir V. Gražulis, „,ūtų neịmanoma, 21 amžiuje atrasti skirtingas kultūras su grynai unikaliais kultūriniais bruožais (folkloru). Derètų pastebèti, jog darbo aplinka ir kultūros vystymosi procesai yra labiau dinaminiai, reflektuojantys globalizacijos tendencijas“ [4, p. 125]. Akivaizdu, jog autoriai atkreipia dėmesị ị tai, jog, atsižvelgiant ị globalizacijos procesus, unikalūs kultūriniai niuansai darbo motyvacijos kontekste tampa minimizuotu iššūkiu Maslowo teorijos poreikių gradacijos idejai. Todèl derètų akcentuoti, jog pozicija šiuo klausimu dažnai neatsiejama nuo kritikų atstovaujamų paradigmų.

Kitas nemažiau svarbus niuansas, susijęs su saviraiškos poreikiu, yra tas, jog, Maslowo požiūriu, saviraiškos potencialas motyvacijos atžvilgiu slypi kiekviename žmoguje. „Visi įrodymai, kuriuos turime, atskleidžia, jog beveik kiekviename žmoguje, ir neabejotinai kiekviename kūdikyje, egzistuoja impulsas sveikatai, valia augimui bei žmogiškojo potencialo realizavimui“ [25, p. 25]. Tačiau akivaizdu, jog ne visi žmonès pasiekia aukščiausią poreikių lygmenị, nors ir saviraiška yra nukreipta i paties žmogaus vidų. C. Rogersas mané, jog dauguma žmonių niekada nepasieks saviraiškos, nes ji neatsiejama nuo asmenybès vidaus atskleidimo, tačiau kitų žmonių reakcijos ị ją ne visada būna teigiamos, o tai gali sukliudyti tolesniam asmens vystymuisi saviraiškos link [5]. Pritariant autoriui, akivaizdu, jog individo formavimasis bei sugebejimai neatsiejami nuo deterministinès patirties, kurios atraminėmis struktūromis tampa sociokultūriniai, psichologiniai ir istoriniai veiksniai. Tačiau straipsnyje gvildenama problema orientuota ne i tai, ar individas pasieks saviraišką, bet ị grynai šios teorinès konstrukcijos sąveiką su valstybès tarnybos sfera. Kaip taikliai pastebi Franklis, ,antropologiniu požiūriu prièmę uždaros sistemos modelį, motyvacijos teorijos požiūriu tampame akli viskam, kas traukia žmogų iš išorès, pastebime tik tai, kas ji stumia iš vidaus, taigi instinktyvias jègas ir impulsus" [13, p. 64]. Jis pateikia naują perspektyvą, susijusią su Maslowo paskutiniuoju saviraiškos poreikiu, įtraukdamas naują savitranscendencijos faktorių. Individualistinè, kulminacinè poreikių hierarchijos išraiška papildoma veiksniu orientuotis ị kitus subjektus, peržengiant asmenines ribas. Franklis [13] teigia, jog būtent sugebejjimas susitelkti ị kažką daugiau nei jis pats, ar tai būtų atsidavimas mylimam žmogui, ar prasmei, vertybèms, atliekamai veiklai, yra aukščiausias poreikių lygmuo. 
Franklio požiūriu [11], saviraiškos kontekste net laimè ir malonumas tèra šalutiniai savitranscendencijos efektai. Iš to galime teigti, jog Franklis laikosi kritinès nuostatos Maslowo faktoriaus atžvilgiu. Taigi sugretinus Maslowo ir Franklio požiūrius pasakytina, jog valia savirealizuotis gali būti papildoma valia siekti prasmès, peržengiant asmenines ribas, realizuotis orientuojantis ị kitus objektus, o ne vien siekiant išreikšti savo vidini potencialą, vadovaujantis grynai individualistiškais motyvais. Savitranscendencijos faktorių paremia ir vertybiniai, organizaciniai tyrimai [37], [38], kurie atskleidé, jog motyvacijos prasme savitranscendenciné, vertybinè dimensija paremta universalizmu ir geranoriškumu. Žmonès, pasižymintys savitranscendencija, organizacinejje aplinkoje yra supratingesni, tolerantiškesni, siekiantys užtikrinti gerovę visiems aplinkiniams, skatinti socialinį teisingumą ir lygybę.

Apibendrindami galime teigti, jog Maslowo motyvacijos teorijos koncepcija nagrinėjama iš įvairių perspektyvų, apžvelgiamas teorijos sklaidos mastas, jos struktūriniai veiksniai, atskleidžiami teorijos privalumai, taip pat analizuojami, autorių nuomone, stipriausi akademiniame diskurse išsakomi kontrargumentai, susiję su teorijos metanaratyviniu statusu bei poreikių gradacijos sistema ir motyvacijos savižudybės atveju klausimais. Maslowo žmogaus poreikių hierarchijos teorija išplèčia motyvacinių priemonių lauką, atkreipdama dèmesị i ịvairius žmogaus faktorius, kuriuos būtina reflektuoti. Teorija pasižymi aiškumu, paprastumu ir intuityvumu, todèl padideja jos pritaikomumo organizacijų valdymo sistemose galimybès, o atliekant grupavimą, susijusị su aukščiausiais, teorijos veiksniais, Maslowo saviraišką pakeičiant Franklio savitranscendencijos komponentu, siūloma ją reintegruoti naujojo viešojo valdymo modelyje viešajame sektoriuje.

\section{Tradicinis viešojo administravimo modelis Maslowo teorijos kontekste}

Pirmojoje straipsnio dalyje iškristalizavus esmines teorijos charakteristikas, šioje dalyje bus siekiama orientuotis ị viešojo administravimo modelių specifiką, siekiant identifikuoti kylančias problemas motyvacijos kontekste, nagrinejjant tradicinio viešojo administravimo modelio struktūrą Maslowo motyvacinès koncepcijos požiūriu. Pasak H. Oweno [31], tradiciniam viešojo administravimo modeliui valstybės tarnautojo atžvilgiu būdingas fiksuotas atlyginimas, statuso išskirtinumas, galimybè dirbti iki senatvès, ịtraukiant pensijos faktorių, santykių nuasmeninimas, taip pat reglamentuotos karjeros perspektyvos. Iš to galime teigti, jog šiame modelyje, jo struktūroje a priori ịtvirtinami tam tikri motyvaciniai komponentai, kuriais buvo siekiama užtikrinti, jog valstybės tarnautojas bus motyvuotas dirbti ir siekti tik valstybės ir visuomenès interesų. Modelio logiką galima būtų sugretinti su Maslowo teorijai būdingais akcentais. Pirmasis veiksnys Maslowo [26] koncepcijoje yra fiziologiniai veiksniai. Siekiant juos patenkinti, yra būtinas atlyginimas, o tradicinis viešojo administravimo modelis užtikrina fiksuotą atlyginimą nepriklausomai nuo darbo rezultatų. Antrasis Maslowo [26] faktorius orientuotas ị indi- 
vido saugumo poreiki, viešojo administravimo institucijos suteikia ịvairaus spektro garantijas, saugią darbo aplinką, tačiau akcentuotina, jog statutinès institucijos pasižymi didesne ir rizikingesne veiklos sfera. Kita vertus, įdarbinimo sąlygos užtikrina ilgalaikę galimybę valstybès tarnautojui dirbti ir tobulèti atitinkamoje srityje nesibaiminant dèl atleidimo. Trečiasis Maslowo [26] išskiriamas akcentas yra meilès ar priklausymo poreikis. Remiantis tradicinio viešojo administravimo modelio struktūra, išskiriant biurokratijos, nuasmeninimo aspektą, paminètina, jog valstybès tarnautojas sutapatinamas su institucija, todèl galime teigti, jog modelio logika taip pat nulemia šio individo poreikio patenkinimą. Valstybès tarnautojas traktuojamas kaip sudètingo biurokratinio aparato dalis, iš išorès tarnautojas ir institucija yra viena ir tas pat [35]. Nors būtina paminèti, jog teisiškai reglamentuoti santykiai nepasižymi ypatingu dėmesiu ar jautrumu individo asmeninėms charakteristikoms, ką akcentuoja vèlesnès vadybinès žmogiškųjų išteklių mokyklos [33]. Ketvirtasis Maslowo [26] teorijos veiksnys susijęs su savivertès poreikiu, kaip normatyvinis, tradicinis viešojo administravimo modelis siekia užtikrinti, jog valstybės tarnyba būtų privilegijuota veiklos sritis, ad hoc valstybès tarnautojas būdamas privilegijuotos profesijos atstovas automatiškai turès galimybę patenkinti savivertės poreikį. Taigi, siekiant adaptuoti Maslowo poreikių hierarchijos logiką viešojo administravimo tradiciniam modeliui, atlikus dviejų koncepcijų sintezę, derètų paminèti ir aukščiausiąji saviraiškos veiksnį. Tradiciniame viešojo administravimo modelyje manoma, jog patenkinus jau minètus valstybès tarnautojo poreikius padideja tikimybè, kaip teigia Maslowas, kad valstybès tarnautojas pereis prie saviraiškos. Patenkinęs žemesniuosius poreikius, pradès rūpintis, kaip atskleisti savo vidini potencialą, o kadangi pačios veiklos srities imperatyvas yra viešujų paslaugų teikimas, viešosios politikos ịgyvendinimas, tai natūraliai turètų jo žmogiškajji potencialą kreipti visuomenès interesų link. Tačiau, straipsnio autorių nuomone, viešojo administravimo kontekste, ypatingai naujosios viešosios vadybos fone, išryškejja amerikietiškojo individualizmo kultūros determinuotos Maslowo aukščiausios saviraiškos veiksnio problema.

\section{Saviraiškos destruktyvumas naujosios viešosios vadybos koncepcijoje}

Antrojoje straipsnio dalyje atskleidę, kaip Maslowo motyvavimo sistemos logika persismelkia tradiciniame viešojo administravimo modelyje, šiame skyriuje autoriai nagrinėja naujosios viešosios vadybos koncepcijos ir motyvacijos santykị, siekdami atskleisti, jog išbalansavus tradicinio viešojo administravimo modelio struktūrą saviraiška valstybės tarnybos kontekste gali turèti destruktyvių padarinių. Naujoji viešoji vadyba dažniausiai suprantama kaip privataus sektoriaus instrumentarijus, valdymo metodų, verslo principų ir vertybių integracija ị viešajji sektorių, siekiant padidinti jo efektyvumą bei konkurencingumą, orientuojantis ị rezultatus [21]. Todèl galime teigti, jog naujoji viešoji vadyba motyvacijos požiūriu viešajam sektoriui buvo nepaprastai svarbi. Verslo sektoriaus organizacijose 
pritaikytos ir patikrintos motyvacijos teorijos, individų poreikių refleksijos taktikos turejo užtikrinti valstybės tarnautojų motyvaciją, taip prisidedant prie viešojo sektoriaus efektyvumo, viešųjų paslaugų kokybės, teigiamo visuomenės požiūrio didinimo bei tinkamų kandidatų į valstybès tarnybą atrankos, taip keliant viešojo sektoriaus įvaizdị.

Pasak J. Palidauskaitès [32], valstybės tarnautojams motyvacija aktuali ne vien tik kaip efektyvaus ir produktyvaus darbo imperatyvas, siekiant gerinti viešųjų paslaugų kokybę, tačiau ir kaip būtinas veiksnys, norint reformuoti ir modernizuoti patị viešąji sektorių. Iš to galime teigti, jog nemotyvuoti valstybès tarnautojai sisteminiu požiūriu gali nepritarti, kliudyti įgyvendinti arba likti indiferentiški viešojo sektoriaus reformoms, naujų viešojo administravimo teorinių bei praktinių modelių diegimui. Užuot prisidejję prie viešojo sektoriaus modelio metamorfozès ir tapę reformatoriais, demotyvuoti valstybès tarnautojai reformų kontekste gali tapti restauratoriais.

Kaip pastebi Donskis, „šioje vietoje pasistenkime atsakyti ị klausimą, kuo reformatoriai skiriasi nuo restauratorių? Juk ir vieni, ir kiti instituciją, valdymą ar sistemą grąžina ị kažkokią prarastą būklę. Skiriasi būtent tuo, kad restauratoriai visuomenę sugrąžina ị tą būklę, kurios ji jau buvo išsižadejjusi, bet kuri buvo ir yra naudinga patiems restauratoriams - sluoksniui, kuris dèl ịvykusių permainų prarado turètą galią bei įtaką" $[9$, p. 30-31].

Sutinkant su autoriumi, galima teigti, jog viešojo sektoriaus tarnautojų motyvacija yra svarbi norint ne vien tiktai užtikrinti viešųjų paslaugų teikimą, bet ir efektyviai bei racionaliai vystyti viešąji sektorių, valstybės valdymą, vengiant pseudoreformų, kurios nepakeičia neigiamos valstybinio aparato būklès teigiama linkme, tačiau grąžina ir pritaiko ją prie motyvaciją praradusių, tačiau galios lauke norinčių išlikti valdininkų ir biurokratų.

Naujosios viešosios vadybos kontekste finansinè logika paremtos motyvacijos sistemos viešajame sektoriuje neturètų būti pagrindinis motyvacinis postūmis. Akivaizdu, jog atlyginimo reikšmė darbuotojams yra pervertinama. Pesimistinis požiūris viešajame diskurse, jog norint kelti valstybės tarnautojų motyvacinị lygmenị būtina didinti atlyginimus, neatitinka realybès. Daug svarbesnis individams saviraiškos poreikis, darbo turinys, pasitenkinimas juo, socialinès, psichologinès priemonès, darbo sąlygos, tarpasmeniniai santykiai su kolegomis bei vadovais. Šias įžvalgas patvirtina ir Lietuvoje Palidauskaitès [32] atliktas valstybės tarnautojų motyvacijos tyrimas. Remiantis tyrimo indikatoriais, akivaizdu, kad įrodymai prieštarauja nusistovejusiom nuostatom dèl finansinio stimulo kaip pagrindinio motyvacinio veiksnio svarbos. Rezultatai atskleide, jog atlyginimo svarba Lietuvos valstybės tarnyboje yra tiktai penktoje vietoje. Pirmoje vietoje respondentai identifikavo troškimą tobulèti, iš to galime teigti, kad šių poreikių pirmenybė sutampa su Maslowo [26] idejja, jog aukščiausias individo motyvacinis lygmuo yra saviraiškos poreikis. Tačiau šioje vietoje išryškejja teorine problema. Maslowo [26] saviraiškos poreikis neatsiejamas nuo individualistinès amerikietiškosios minties. Pats saviraiškos 
veiksnys yra egoistinis, savanaudiškas imperatyvas, orientuotas $i$ asmeninị individo potencialo realizavimą. Net jeigu ir prieš saviraišką einantys individo poreikiai bus patenkinti, aukščiausiasis lygmuo, arba kitaip saviraiškos motyvacinis normatyvas, vis tiek yra orientuotas ị patị individą. Šio veiksnio problemą dar labiau sustiprina viešojo pasirinkimo teorija, kuri valstybès tarnautojus traktuoja kaip savo ekonominę naudą siekiančius maksimizuoti individus. Paminètina, jog naujosios viešosios vadybos principai, siekiant efektyvumo bei rezultato, išbalansuoja tradiciniame viešojo administravimo modelyje nusistovejusią logiką valstybès tarnautojų apriorinių poreikių patenkinimo atžvilgiu. Naujoji viešoji vadyba akcentuoja privačiajame sektoriuje įsigalejjusią kontraktų su valstybės tarnautojais sistemą [34]. Tokiu būdu daromas poveikis individo saugumo poreikiui. Šio modelio kontekste jis patenkinamas tik iš dalies, nes sutartis su juo gali būti nepratęsiama. Tas pats principas galioja ir atlyginimo atžvilgiu, atlyginimas priklauso nuo rezultatų, o ne vien nuo stažo ar kvalifikacijos. Pabrèžtinas ir privatizacijos aspektas, valstybinio aparato mažinimas, todèl kyla grèsmè valstybès tarnautojo darbo vietai. Todèl darome teorinę prielaidą, jog tradicinio modelio reformacija Maslowo [26] žmogaus poreikių hierarchijos kontekste padidins tikimybę, jog valstybės tarnautojui siekiant saviraiškos padidès ir korupcinè motyvacija, siejant ją su dẻl nevisapusiško žemesniųjų poreikių patenkinimo kylančiomis frustracijomis. Vadinasi, tampa akivaizdu, jog, integruojant šią privačiame sektoriuje paplitusią motyvacinę praktiką, sunku išvengti galimų ịtampų tarp žmogaus egoistinių motyvų, individualizmo, nukreipto ị asmeninį interesą, bei viešojo intereso, visuomenės gerovės ir jos poreikių. Remiantis tuo, derètų kritiškai vertinti saviraiškos aspektą bei galimas jo neigiamas, o kartais net destruktyvias implikacijas valstybės tarnautojų vertybinėms orientacijoms.

Kaip alternatyvą Maslowo [26] individualistiniam veiksniui saviraiškai dar besiformuojančio viešojo administravimo naujojo viešojo valdymo kontekste siūloma aukščiausią Maslowo motyvacinį normatyvą - saviraišką - pakeisti ịdiegiant Franklio savitranscendencijos faktorių, taip papildant ir reintegruojant Maslowo poreikių hierarchijos teoriją.

Akcentuotina, jog Franklio požiūris artimas ir krikščioniškai kultūrai būdingai normatyvinei gyvenimo motyvacijos formai tarnauti kitiems žmonėms, taip tarnaujant Dievui [10]. Paminètina ir tai, jog savitranscendencija galètų tapti atkirčiu Maslowo natūralistinèms pozicijoms bei materialistinès, individualistinès filosofijos apraiškoms motyvacijos kontekste. Šis komponentas kaip vertybinis orientacinis normatyvas galètų prisidèti ir prie etinio valstybės tarnautojo kontrolès mechanizmo naujajame viešajame valdyme, kurio poreikị indikuoja A. Guogis ir D. Gudelis [16]. Savitrasncendencijos faktoriaus įdiegimas nereikalautų papildomų valstybės lèšų, o vien tik vadovų vadybinių, psichologinių žinių tobulinant valstybẻs tarnautojų motyvacinę percepciją.

Pasak Franklio [21], žmogaus galimybe orientuotis i kažką daugiau nei jis pats - ar tai būtų prasmè, vertybès, individo mylima veikla, ar kiti žmonès - yra 
aukščiausias poreikių lygmuo. Viešojo administravimo kontekste tai galėtų būti visuomenè, valstybès tarnautojo siekis susitelkti ị atliekamą veiklą, puoselëjant demokratines vertybes, socialinį teisingumą, lygybę, pagarbą žmogui. Peržengiant asmenines ribas, tam tikra prasme save realizuojant, tačiau puoselèjant etiką, moralę, orientuojantis ne į asmeninę naudą ar individualistinę ego išraišką, o ị pilietinę visuomenę, viešojo administravimo tikslus, atliekant valstybės tarnautojo pareigas remiantis savo sąžine bei pagrindiniais demokratiniais principais.

Apibendrindami galime teigti, jog savitranscendencijos faktorius valstybės tarnyboje naujojo viešojo valdymo kontekste galètų turèti rimtų implikacijų ir sprendžiant viešojo sektoriaus korupcijos problemas. Naujojo viešojo valdymo administravimo modelis, įtraukiant Franklio savitranscendenciją, motyvacijos požiūriu vertybiškai determinuotų motyvacines kryptis, kurios būtų nesutaikomos su korupciniu, nusikalstamu elgesiu bei galètų inspiruoti moralinio jautrumo puoselèjimą ir skatinimą piliečiu atžvilgiu.

\section{Išvados}

Išanalizavus Maslowo teorijos anatomiją, identifikavus jos paprastumą, estetiškumą ir intuityvumą bei atsižvelgiant ị poreikių hierarchijos teorijos sklaidą ivvairaus spektro tyrimuose skirtingame sociokultūriniame lauke, pagrindžiamas šios teorijos aktualumo ir pritaikomumo klausimas, rekomenduojant ją viešojo sektoriaus institucijų vadovams, siekiant patenkinti motyvavimo sistemos poreikị viešojo administravimo kontekste.

Išnagrinèjus tradicinį viešojo administravimo modelį remiantis Maslowo teorijos struktūra paaiškejo, jog egzistuoja loginis santykis tarp tradicinio modelio motyvacinės konstrukcijos ir Maslowo poreikių hierarchijos idejos, nors pastaroji sukurta vèliau. Naujosios viešosios vadybos modelio fone atkreipiamas dèmesys i Maslowo teorijos aukščiausiojo saviraiškos veiksnio ir paties modelio struktūros sustiprinto individualizmo, ekonomizacijos aspektų galimas implikacijas korupcinès aplinkos valstybès tarnyboje ịsivyravimui. Siekiant spręsti šią problemą naujojo viešojo valdymo kontekste, siūloma reintegruoti Maslowo teoriją, papildant ją Franklio savitranscendencijos faktoriumi.

Atliekant Maslowo poreikių hierarchijos teorijos aukščiausių veiksnių grupavimą, saviraišką pakeičiant savitranscendencija, būtina akcentuoti, jog savitranscendencija naujojo viešojo valdymo kontekste negarantuoja, jog valstybès tarnautojas pradès orientuotis ị visuomenės narius, tačiau šiuo konstruktu motyvacinejje perspektyvoje yra nubrèžiamos normatyvinès kryptys, kurios padidina šios elgsenos tikimybę.

\section{Literatūra}

1. Alderfer, C. P. Existence, Relatedness, and Growth; Human Needs in Organizational Settings. New York: Free Press, 1972. 
2. Al-Meer, A. R. A comparison of the need importance structure between Saudis and westerners: An exploratory study. Journal of Management Development, 1996, Vol. 15, Iss: 5, 56-64.

3. Barnes, S.; Pressey, A. D. Who needs cyberspace? Examining drivers of needs in Second Life, Internet Research, 2011, Vol. 21, Iss: 3, 236-254.

4. Blaskova, M.; Gražulis, V. Motivation of human potencial: Theory and practice. Vilnius: Mykolas Romeris university, 2009.

5. Cameron, J. D.; Pierce, W. Rewards and Intrinsic Motivation: Resolving the Controversy. Westport, CT, USA: Greenwood Press, 2002.

6. Cao, H.; Jiang, J.; Bin Oh, L.; Li, H.; Liao, X.; Chen, Z. A Maslow's hierarchy of needs analysis of social networking services continuance. Journal of Service Management, 2013, Vol. 24, Iss: 2, 170-190.

7. Chalofsky, N. E. Meaningful Workplaces: Integrating the Individual and the Organization. Hoboken, NJ, USA: Jossey-Bass, 2010.

8. Charnov, B. H.; Weisbord, E.; Lindsey, J. Managing People in Today's Law Firm: The Human Resources Approach to Surviving Change. Westport, CT, USA: Greenwood Press, 1995.

9. Donskis, L. Tyliosios alternatyvos: Socialinès analizès ir kritikos eskizai. Vilnius: Versus aureus, 2008.

10. Francis, L. J.; Atkins, P. Exploring Matthew's Gospel: A Guide to the Gospel Readings of the Revised Common Lectionary. London, GBR: Continuum International Publishing, 2005.

11. Frankl, V. E. The Unconscious God: Psychotherapy and Theology. New York: Simon and Schuster, 1975.

12. Frankl, V. E. Žmogus ieško prasmès. Vilnius: Katalikų pasaulio leidiniai, 2009.

13. Frankl, V. E. Žmogus prasmès akivaizdoje. Vilnius: Katalikų pasaulio leidiniai, 2010.

14. Gobin, B. A.; Bye Becceea, N.; Teeroovengadum, V. Investigating into the Relationship between the Present Level of Tertiary Students' Needs Relative to Maslow'sHierarchy: A Case Study at the University of Mauritius. The International Journal of Learning, 2012, Volume 18, Iss: 11, 203-219.

15. Gruyter, de W. Gruyter Studies in Organization: Managing Organisations in Africa. Berlin, DEU: Walter de Gruyter, 2011.

16. Guogis, A.; Gudelis D. Viešojo administravimo ir verslo vadybos integracijos perspektyvos: viešojo ir privataus sektorių sąveikos modelis. Viešoji politika ir administravimas, 2009, 28, 23-28.

17. Herzberg, F. The Motivation to Work. New York: John Wiley and Sons, 1959.

18. Keogh, P. Motivation for grant writing among academic librarians. New Library World, 2013, Vol. 114, Iss: 3/4, 151-165.

19. Kermally, S. Gurus On People Management. London, GBR: Thorogood Publishing, 2005.

20. Kumar, N. Organizational Behaviour: A New Look: Concept, Theory and Cases. Mumbai, IND: Global Media, 2009.

21. Lane, J. E. New Public Management. London, GBR: Routledge, 2000.

22. Loytard, J. F. Postmodernus būvis. Vilnius: Baltos lankos, 1993. 
23. Maddock, R. C.; Fulton, R. L. Motivation, Emotions \& Leadership: The Silent Side of Management. Westport, CT, USA: Greenwood Press, 1998.

24. Mamoun, N.; Akroush, Amjad A.; Abu-ElSamen, Ghazi A.; Samawi, Abdelhadi L. Odetalla. Internal marketing and service quality in restaurants. Marketing Intelligence \& Planning, 2013, Vol. 31, Iss: 4, 304-336.

25. Maslow, A. H. The farther reaches of human nature. New York, USA: The Viking Press, 1972, 25.

26. Maslow, A. H. A Theory of Human Motivation. Psychological Review, 1943, 50(4), 370-396.

27. Maslow, A. H. Motivation and Personality. New York: Harper and Row, 1954.

28. McCleland, D. C. The achieving society. Van Nostrand: Yhe.University of Michigan, 1961.

29. McGregor, D. The Human Side of Enterprise. New York: McGraw Hill, 1960.

30. Olu Ogunrin, F., Ogunrin, O., Akerele, A. Motivating Nigerian doctors for improved health care delivery. International Journal of Health Care Quality Assurance, 2007, Vol. 20, Iss: 4, 290-306.

31. Owen, H. E. Public Management and Administration: An Introduction. Gordonsville, VA, USA: Palgrave Macmillan, 2003.

32. Palidauskaite, J. Motyvacijos unikalumas valstybès tarnyboje. Viešoji politika ir administravimas, 2007, 19, 33-45.

33. Perry, J. L. (Ed.), Hondeghem, A. (Ed.). Motivation in Public Management: The Call of Public Service. Oxford, GBR: Oxford University Press, 2008.

34. Raipa R. Šiuolaikinio viešojo valdymo kryptys ir tendencijos. Viešoji politika ir administravimas, 2009, 30, 22-32.

35. Rathod, P. B. Comparative Public Administration. Jaipur, IND: Global Media, 2007.

36. Robbins S. P. Organizacinés elgsenos pagrindai. Kaunas: Poligrafija ir informatika, 2003.

37. Sagiv, L.; Schwartz, S. H. Cultural values in organisations: insights for Europe. European Journal of International Management, 2007, Vol. 1, No. 3, 176-90.

38. Sagiv, L.; Schwartz, S. H. Value priorities and subjective well-being: direct relations and congruity effects. European Journal of Social Psychology, 2000, Vol. 30, 177-98.

39. Stivers, C. Governance in Dark Times: Practical Philosophy for Public Service. Washington, DC, USA: Georgetown University Press, 2008.

40. Stoner, J. A.; Echvard, F. F.; Gilber, D. R. Jr. Vadyba. Kaunas: Poligrafija ir informatika, 1999.

41. Stum, D. L. Maslow revisited: building the employee commitment pyramid. Strategy \& Leadership, 2001, Vol. 29, Iss: 4, 4-9.

42. Tikkanen, I. Maslow's hierarchy and pupils' suggestions for developing school meals. Nutrition \& Food Science, 2009, Vol. 39, Iss: 5, 534-543.

43. Wahba, A.; Bridwell, L. Maslow reconsidered: A review of research on the need hierarchy theory. Organizational Behavior and Human Performance, 1976, (15): $212-240$. 


\title{
Ramūnas Vanagas, Adomas Vincas Rakšnys \\ Motivation in Public Sector - Motivational Alternatives in the Maslow's Hierarchy of Needs
}

\begin{abstract}
The significance of Maslow theory of human needs remains in the various organizations because of its simplicity and adaptability. In order to meet the motivational system need in public sector and saving public money, the theory based on the psychological factors must be considered. The article disclose the application of theory finding that the theory of a priori structure has been established in the traditional public administration model. Reviewing the dissemination of the theory in the background of New Public Management and indicating possible negative implications for the civil servants emerged due to self- actualization of the highest factor of motivation theory, it is proposed to re-integrate the theory of Maslow implementing Frankl's self-transcendence factor in the New Governance.
\end{abstract}

Ramūnas Vanagas - Mykolo Romerio universiteto Politikos ir vadybos fakulteto Vadybos instituto docentas, socialinių mokslų daktaras.

E. paštas: rvanagas@mruni.eu

Adomas Vincas Rakšnys - Mykolo Romerio universiteto Politikos ir vadybos fakulteto Viešojo administravimo magistrantas.

E. paštas: e_cnv@yahoo.com

Ramūnas Vanagas, PhD. Associate Professor at the Institute of Management, Faculty of Politics and Management, Mykolas Romeris University.

E-mail: rvanagas@mruni.eu

Adomas Vincas Rakšnys, Master studies student, Faculty of Public Administration, Mykolas Romeris University.

E-mail: e_cnv@yahoo.com

Straipsnis įteiktas redakcijai 2013 m. kovo mėn.; recenzuotas, parengtas spaudai $2014 \mathrm{~m}$. gegužès $24 \mathrm{~d}$. 